\title{
Rekonstruksi Pembelajaran Perbankan Syariah Pada Perguruan Tinggi Islam
}

\author{
Juwita Anggraini ${ }^{1}$, Maya Panorama ${ }^{2)}$ \\ ${ }^{1,2}$ Fakultas Ekonomi dan Bisnis Islam UIN Raden Fatah \\ *Email korespondensi: Juwita_uin@radenfatah.ac.id
}

\begin{abstract}
In the perception of the human capital of Islamic banking that is needed is (1) having good language skills and must be able to communicate effectively; (2) Banks demand human resources to be able to establish good cooperation, able to present material in public well and able to think critically; (3) Islamic banks also demand that human resources have good knowledge about contracts and transactions. This requires universities to carry out reconstruction of learning that is in line with Islamic banking needs. In this study found several steps in the reconstruction of banking learning including determining the achievement of banking learning, determining competencies, adjusting the curriculum, determining indicators of Islamic banking, media and learning methods and so forth.
\end{abstract}

Keywords: reconstruction, learning, islamic banking.

Saran sitasi: Anggraini, J., \& Panorama, M. (2020). Rekonstruksi Pembelajaran Perbankan Syariah Pada Perguruan Tinggi Islam. Jurnal Ilmiah Ekonomi Islam, 6(03), 621-628. doi:http://dx.doi.org/10.29040/jiei.v6i3.1390

DOI: http://dx.doi.org/10.29040/jiei.v6i3.1390

\section{PENDAHULUAN}

Kebutuhan Sumber daya manusia yang ada di dunia perbankan syariah dari tahun ke tahun terus meningkat. Hal ini ditunjukan dari pernyataan ketua umum masyarakat Ekonomi Syariah (MES), Muliaman D Hadad yang menyatakan bahwa "kebutuhan tenaga kerja untuk perbankan syariah menigkat signifikan sejak 5 (lima) tahun terakhir,dengan perkembangan industry keuangan syariah maka kebutuhan SDM pun akan terus meningkat (www.ekonomisyariahorg). Sejalan dengan pernyataan diatas Harisman (Direktur Direktorat Pebankan Syariah Bank Indonesia mengatakan bahwa emapat sampai lima tahun yang akan datang dibutuhkan 10 ribu SDM untuk mengisi industry perbankan Syariah (Muthe, 2012).

Melihat tingginya tingkat kebutuhan sumber daya manusia diatas ini membuka kesempatan bagi para alumni perbankan syariah pada khususnya dan ekonomi Islam pada umumnya. Namun kesempatan besar ini juga harus diimbangi dengan tingkat siap pakai dari para alumni tersebut. Dari tahun ke tahun tuntutan kompetensi Sumber daya manusia pada perbankan semakin tinggi. Dari data yang ada alumni perguruan tinggi khususnya pada program studi ekonomi Islam atau perbankan syariah kurang memiliki keterampilan pada dunia kerja di perbankan syariah. Hal ini sesuai dengan pernyataan Prof. Teuku Yuri bahwa umumnya yang disiapka perguruan tinggi tidak sejalan dengan apa yang dibutuhkan oleh industry. Secara khusus perguruan tinggi teoritis dalam pengajaran dan mengikuti system luar negeri. Menurut Mustofa Edwin Nasution (Mantan Ketua Umum IAEI) menyatakan bahwa baru sekitar 20-an universitas yang mengambil peran penciptaan SDM perbankan syariah. Itupun hanya 1000 -an orang yang berhasil diluluskan setiap tahunnya (Mohammad Nur dkk, 2016).

Dari beberapa kasus menunjukan bahwa meningkatnya kuantitas SDM yang ada di perbankan syariah tidak diimbangi dengan kualitas yang memadai. Minimnya lulusan perguruan tinggi yang paham ekonomi syariah membuat sebagian bank yang membuka office channeling memilih mentransfer pegawai dari bank konvensional, sehingga ini menjadikan bank syariah yang bercitarasa konvensional. Pencapaian kualiatas SDM pada perbankan syariah harus dilakukan dengan berbagai 


\section{Jurnal Ilmiah Ekonomi Islam, 6(03), 2020, 622}

cara, karena banyak dampak negative bagi bank syariah apabila melakukan office Chanelling. Hal ini menyebabkan 90\% SDM yang ada diperbankan syariah saat ini tidak memiliki latar belakang pendididkan perbankan syariah.(Riset Universtias UI:2010) (Esy Nur Aisyah dkk, 2018). Di sisi lain menurut Wahyu Dwi Agung (Mantan Ketua Asbindo) SDM perbankan syariah saat ini juga hanya $10 \%$ berlatar belakang pendidikan perbankan syariah dan $90 \%$ berlatar belakang konvensional yang "dikarbitkan" melalui pelatihan singkat perbankan syariah.

Sementara itu hasil penelitian Euis Amalia (2009:10) mempelihatkan bahwa dalam persepsi perbankan syariah SDM yang dibutuhkan oleh bank syariah adalah (1) memiliki kemampuan bahasa yang baik dan harus mampu mengadakan komunikasi secara efektif baik pada internal bank maupun kepada nasabah dan stakeholder; (2) Bank menutut SDM mampu menjalin kerja sama secara baik, mampu mempresentasikan materi dihadapan public dengan baik, dan mampu berpikir secara konseptual, rasiona, sitematis dan kritis; (3) Bank syariah juga mengharuskan SDM memiliki pengetahuan yang baik tentang akad dan transaksi syariah (4) selain itu juga bank syariah membutuhkan SDM customer focus yang mengedepankan service excelen dan innovation yang didapatkan di bangku kuliah (Esy Nur Aisyah dkk, 2018).

Diskursus tersebut menunjukan bahwa pembelajaran perbankan syariah saat ini di Indonesia, khususnya perguran tinggi Islam belum memenuhi tingkat kebutuhan dari pihak perbankan syraiah yaitu tenaga kerja yang siap pakai bagi perbankan syariah. Dalam hal ini penting sekali Perguruan tinggi melakukan rekonstruksi pembelajaran perbankan syariah. Hal ini tidak hanya sekerdar merumuskan dan pola pengajaran yang baik tetapi juga perlu memastikan bahwa kurikulum yang dibuat relevan dengan kebutuhan user yaitu perbankan syaiah.

\section{METODE PENELITIAN}

Karena merupakan sebuah refleksi kritis atas realitas pengungkapan pemaknaan metode penelitian ini menggunakan pendekatan analisis kualitatif. Menggunakan ketajaman analisis atas realitas masyarakat yang ada, ditopang oleh referensi yang relevan dengan topik yang dikembangkan, penulis melakukan sebuah rekonstruksi pembelajaran matakuliah untuk menemukan kurikulum dan strategi penting dalam merumuskan kembali bentuk pembelajaran perbankan syariah. Data dalam penelitian ini terdiri dari dua, yaitu data primer dan data sekunder. Data primer terdiri dari kuisioner dan wawancara serta hasil dari Focus Group Discussion (FGD). Sementara data sekunder diperoleh dari dokumen-dokumen tertulis dan literature-literatur perpustakaan yang terkait denngan pengembangan pembelajaran perbankan syariah.

Dalam Penelitian ini responden penelitian terdiri dari Perguruan Tinggi Islam yang berada di wilayah Sumatera bagian Selatan Diantaranya, UIN Raden Fatah Palembang, UIN Raden Intan Untuk Lembaga perbankannya responden yang dipilih diantaranya Bank Sumsel Babel Syariah, Bank Syariah Mandiri dan Bank Rakyat Indonesia. Pemilihan bank-bank tersebut karena dari survey sebagain alumni dari Program Studi Perbankan syariah bekerja di bankbank tersebut.

Data yang terkumpul dianalisis melalui content analysis yakni dengan cara mengukur bentuk kurikulum, model pembelajaran dan strategi yang ada lalu merumuskan formula yang baru dan diberi rekomendasi dan kesimpulan. Dalam proses analisis data digunakan prosedur dari Mathew B. Miles dan A. Michael Hubberman, yang mencakup tiga kegiatan, yaitu reduksi data, display data, dan verifikasi serta kesimpulan

\section{HASIL DAN PEMBAHASAN}

\section{Urgensi Rekonstruksi Pembelajaran Perbankan Syariah}

Narasumber menyatakan bahwa pembelajaran dalam perguruan tinggi merupakan seperangkat pengamalan belajar yang diorganisasikan dan direncanakan. Pengorganisasian dan perencanaan dalam permbelajaran memiliki tujuan yang akan menghasilkan outcome yang jelas dalam suatu matakuliah. Kurikulum perbankan syariah di suatu perguruan tinggi dengan kebutuhan sumberdaya manusia di Industri perbankan syariah, belum memenuhi kriteria yang dibtuhkan oleh pihak perbankan.

Hasil penelitian diatas juga diperjelas dari pernyataan disampaikan oleh Ary Ysuniari dalam workshop kurilulum bahwa alumni perbankan syariah pada PTAIN belum menjawab atas kepentingan dari perbankan syariah. Kebutuhan sumber daya manusia pada perbankan syariah saat ini harus memiliki baik keilmuan soft Skill dan Hard Skill. Hard Skill 


\section{Jurnal Ilmiah Ekonomi Islam, 6(03), 2020, 623}

diperoleh dari berbagai materi yang diberikan oleh fakultas yang mencakupi beberapa teori perbankan. Perguruan tinggi biasanya mermberikan porsi leih besar untuk menghasilkan hard skill. Namun pihak perbankan syariah kecenerungan menggunakan tenaga sumber Manusia yang siap pakai baik untuk aplikasi perbankan dan pelayanan.

"Karyawan yang ada di bank kami terdiri dari berbagai bidang pendidikan, ada yang berlatar belakang pendidikan guru, manajemen, ekonomi Islam, d3 perbankan syariah dan lain sebagainya. Karena itu dalam perektrutan yang kami nilai tidak hanya keilmuan tetetapi juga keterampilan dan keahlian. Banyak sekali karyawan kami yang memiliki latar belakang bukan ilmu ekonomi tetapi secara keterampilan mereka dapat mengerjakan pekerjaan yang ada diperbankan. Namun fenomena yang menarik justru karyawan yang memiliki latar belakang perbankan syariah yang tidak begitu menguasai secara keterampilan. Oleh karena itu kami mengharapkan adanya kerja sama antara perguruan tinggi dan perbankan untuk merumuskan kurikulum perbankan syariah agar dapat bersesuaian dengan kebutuhan yang ada pada bank.

Sementara kurikulum dan kajian yang ada terhadap kurikulum terkait perbankan hanya sebatas teori yang bersifat parsial belum integral seperti mengunakan buku-buku berikut ini (Abdul Wahab and others ):

a. Bank syariah dari Teori ke Praktek, Syafe'i Antonio, hanya membahas tentang gambaran umum bank syariah, operasional Bank Syariah, produk-produk, akad-akad dan lain sebagainya

b. Memahami Bank Syariah, oleh Zainal Aripin, Mantan Dirut Bank Muamalat, pembahasannya hanya seputar prospek masa depan perbankan syariah, peluang dan tantangan Bank Syariah serta strategi pengembangan perbankan syariah

c. Kurikulum Tingkat Satuan Pendidikan (KTSP), Karangan HE. Mulyasa, secara dan strategi pendidikan menurut KTSP

d. Manajemen Sumber Daya Manusia, oleh SP Hasibuan, membahas tentang gambaran umum SDM, urgensi manajemen sumber daya manusia, komponen-komponen manajemen sumber daya manusia serta metode pendekatan manajemen sumber daya manusia

Di lihat dari sumber pembelajaran diatas hanya menghasilkan kemampuan secara kognitif tetapi tidak menghasilkan kemampuan secara kreatif, inovatif yang dibutuhkan oleh perbankan syariah. Sementara itu pada tataran teoritis dan konseptual, industri perbankan syariah masih merasakan sangat kekurangan sumber daya manusia yang benar-benar mendalami ushul fiqh, muamalah, qawaid fiqihyah, dan sekaligus ilmu keuangan modern. Sumber daya manusia seperti ini sangat langka untuk perbankan syariah, hal ini terjadi bukan hanya di Indonesia tetapi juga banyak negara termasuk negara lain yang perkembangan ekonomi Islamnya cukup pesat. Pada umumnya Sumber daya manusia dalam perbankan syariah saat ini adalah mereka fasih berbicara terntang ilmu ekonomi kontemporer tetapi lemah terhadap konsep ushul fiqh atau fiqh muamalah atau sebaliknya, banyak ahli yang mahir terhadap teori akad-akad dalam fiqh muamalah tetapi lemah dalam memahami tentang ilmu keuangan. Untuk memproduksi alumni yang memiliki pemahaman secara konseptual terhadap akad-akad yang harus ada dalam suatu perbankan syariah serta juga memahami terhadap ilmu keuangan secara aplikatif, amak dibutuhkan beberapa starategi yang harus dilakukan oleh suatu perguruan tinggi.

Melihat fenomena diatas dapat dipahami bahwa perguruan tinggi belum dapat menjawa terhadap tantangan dari perkembangan duania perbankan terkait pengembangan SDM untuk itu dibutuhkan beberapa strategi untuk menjawab permasalahan ini, seperti yang ditawarkan oleh Euis Amalia dalam penelitiannya mengungkapkan beberapa stratetgi yang dapat dilakukan diantaranya.

a. Memperbaiki kualitas pengajar. Pengajar merupakan salah satu kunci penting pada perguruan tinggi. Perguruan tinggi Agama Islam memiliki keuanggulan tenaga pengajar yang handal pada penguasaaan aspek ilmu-ilmu kesyariahan, sementara perguruan tinggi umum memiliki kekuatan tenaga pengajar yang handal dalam pengauasaan aspek ekonomi. Sementara itu merupakan kelemahan perguruan tinggi yatu kurang bahkan sulit sekali keresediaan sumber daya tenaga pengajar integratif yang mampu memadukan antara aspek ilmu syariah dengan aspek ilmu ekonomi.

b. Memperbaiki kurikulum dan Kompetensi Inti. Pada saat ini belum ada kebijakan secara nasional terkait standarisasi kurikulum perbankan syariah. Selama ini kurikulum inti hanya disepakati dan disusun oleh perguran tinggi itu sendiri dengan 


\section{Jurnal Ilmiah Ekonomi Islam, 6(03), 2020, 624}

melibatkan stakeholder terkait, sehingga memiliki kesan adanya kebebasan kurikulum.

c. Memperbaiki struktur akademik posisi kajian Perbankan Syariah. Kajian perbankan syariah harus terus dilakukan pembaharuan-pembaharuan sesui dengan kebutuhan zaman. Banyak sekali akad-akad pada perbankan syariah harus melalui pengkajian yang diadakan oleh perguran tinggi, sehingga dari hasil pengkajian tersebut didapatkan sebuah hasil yang dapat dikonsumsi oleh mahasiswa sebagai calaon sumber daya manusia perbankan syariah.

d. Memperbaiki sarana praktikum, sistem informasi dan akses refenrsi masih terbatas. Dibeberapa perguruan tinggi umum dan perguruan tinggi agama Islam saran dan prasarana telah cukup memadai. Dalam berbagai kebutuhan akan fasilitas masih menunjukan kekurangan bai kualitas maupun kuantitias. Di beberapa perguruan tinggi hal ni masi menjadi kendala dalam pembelajaran.

e. Memperbaiki kebijakan pimpinan dan kultur akademik. Pada beberapa perguruan tinggi, perkembangan kajian ekonomi Islam sangat didukung oleh pimpinan.

Strategi diatas dapat dipahami bahwa perlu adanya rekonstruksi pembelajaran perbankan syariah, sebagaimana diketahui bahwa pembelajaran adalah proses pemberdayaan potensi peserta didik dalam menemukan kompetensi. Untuk menghasilkan kompetensi yang diharapkan kedepan maka diperlukan penyesuaian-penyesuain sesuai dengan kondisi dan tuntutan masyarakat terhadap sesuatu tujuan dari pendidikan. Rekonstruksi pembelajaran perbankan syariah diperlukan karena berbagai kondisi dan tuntutan user selama ini tidak terpenuhi dari kompetensi yang dilahirkan oleh perguruan tinggi. Pertimbangan dari data-data diatas yang memperlihatkan permasalahan yang cukup rumit terkait kebutuhan user dan pembelajaran yang ditawarkan perguruan tinggi tidak mencapai link and mage. Secara konseptual ada beberapa alasan terkait rekonstruksi pembelajaran diantaranya, hasil belajar mahasiswa tidak memuaskan (hasil yang man, aspek apa, apakah karena proses instruksional/pembelajaran), perkembangan ilmu pengetahuan dan teknologi, perubahan kebijakan pemerintah, pendekatan interdisipliner dan multidisiplin serta rancangan yang telah ada disusun oleh orang lain.
Berdasarkan hasil pengelolaan data pada pembelajaran perbankan syariah menjawab semua alasan tersebut. Pertama, hasil belajar mahasiswa tidak memuaskan, hal ini ditunjukan bahwa mahasiswa tidak menguasai terhadap keilmuan perbankan syariah yang dibutuhkan oleh perbankan syariah, seperti yang telah dikaji sebelumnya perbankan syariah mengharapkan lulusan perbankan syariah menguasaia terhadap kompetensi utama yang harus dimiliki oleh alumni (Wawancara dengan Herman (Kepala Kantor Cabang UIN Raden Fatah Bank Sumsel Babel)pada tanggal 12 April 2020). Hal ini disebabkan oleh beberapa faktor diantaranya kurikulum yang tidak komprehensif menyajikan matakulih-mata kuliah yang terkait normatif dan aplikatif perbankan syariah, tenaga pengajar yang kurang menguasai terhadap bidang kajian dan aplikatif dan lain sebagainya. Kedua, Perkembangan ilmu pengetahuan dan teknologi. Sebagaimana kita ketahui bahwa teknologi perbankan syariah sangat ini mengalami perkembangan yang cukup pesat. Perkembangan teknologi dan ilmu pengetahuan yang semakin pesat telah memberikan peranan ke segala sektor, salah satunya sektor keuangan dan perbankan. Di dalam sektor keuangan dan perbankan, peranan dari perkembangan teknologi operasional dan sistem informasi telah menghadirka berbagai bentuk layanan yang tersaji dalam bentuk mobile banking. Pembelajaran perbankan syariah pada saat ini belum mampu menyajikan perkembangan teknologi pada saat ini. Materi-materi maupun matakuliah yang memperlihatkan inovasi dalam perbankan syariah belum tersentuh. Ketiga, Pendekatan interdisipliner dan multidisipliner. Pendekatan ini merupakan pendekatan yang menyajikan pembelajaran perbankan syariah yang menggunakan berbagai disiplin ilmu. Dalam pembelajaran perbankan syariah matakuliah yang terkait teoritis harus dapat diimplimentasikan dalam kehidupan secara aplikatif. Ketiga alasan dalam merekonstruksi suatu pembelajaran ini menjadi dasar maka rekonstruksi pembelajaran perbankan syariah harus dilakukan.

\section{Rekonstruksi Pembelajaran Perbankan Syariah di Perguruan Tinggi}

a. Analisis Tujuan Pembelajaran (Merumuskan Capaian Pembelajaran/ Kompetensi yang diharapkan)

Pembelajran yang berbasis pada kompetensi yang diharapkan di beberapa Lembaga Keuangan Syariah termasuk dalam hal ini Lembaga Bank 


\section{Jurnal Ilmiah Ekonomi Islam, 6(03), 2020, 625}

Syariah meliputi standar kompetensi dasar yang harus diterapkan dan dipelajari oleh Program Studi Perbankan Syariah dan perguruan tinggi. Adapun

\begin{tabular}{|c|l|}
\hline NO & Kompetensi Dasar \\
\hline 1 & Menerapkan Dasar-dasar pada perbankan Syariah \\
\hline & Memahami Lembaga Keuangan Selain Bank \\
\hline & Memahami Fiqh Muamalat \\
\hline & Memahami Ekonomi Islam \\
\hline &
\end{tabular}

(2)

Sumber: Dokumentasi, Katalog perbankan syariah, Data diolah kompetensi yang diterapkan dan dipelajari Program Perbankan syariah Fakultas Ekonomi dan Bisnis Islam adalah sebagai berikut:

Kompetensi Utama
Menerapkan Aspek Manajemen Pada Bank Syariah
Menerapkan dan mengelola pembiayaan
Mengelola Transaksi Bidang dana syariah
Mengelola administrasi perpajakan
Mengelola Siklus Akuntansi Jasa dan Dagang
Memproses dokumen dana kas di kas bank
Memproses dokumen dana
Mengelola laporan keuangan
Mengelola komputer akuntansi

b. Menentukan indikator pembelajaran

Langkah selanjutnya dalam melakukan rekonstruksi pembelajaran perbankan syariah FEBI UIN raden Fatah adalah menentukan indikator pembelajaran. Indikator pembelajaran dilakukan dengan melihat ketercapaian yang diharapkan dari

\begin{tabular}{|c|c|c|}
\hline $\begin{array}{l}\text { Kompetensi } \\
\text { dasar }\end{array}$ & Indikator & $\begin{array}{c}\text { Pengalaman } \\
\text { Pembelajaran }\end{array}$ \\
\hline $\begin{array}{l}\text { Perkembangan } \\
\text { Ilmu Ekonomi } \\
\text { Islam }\end{array}$ & $\begin{array}{l}\text { Setelah mengikuti perkuliahan mahasiswa diharapkan dapat } \\
\text { menejelasikan: } \\
\text { 1. Tentang perbedaan sejarah perkembangan Ilmu ekonomi Islam } \\
\text { 2. Perbedaan: Ciri-ciri perkembangan ilmu ekonomi Islam dan Ilmu } \\
\text { ekonomi kovensional } \\
\text { 3. Perkembangan ilmu ekonomi Islam di Indonesia } \\
\text { 4. Menjelaskan hubungan ilmu ekonomi dengan kebutuhan } \\
\text { lembaga dan masyarkat }\end{array}$ & $\begin{array}{l}\text { Perkembangan } \\
\text { Ilmu Ekonomi } \\
\text { Islam }\end{array}$ \\
\hline $\begin{array}{l}\text { Memahami } \\
\text { konsep } \\
\text { Ekonomi } \\
\text { Syariah }\end{array}$ & $\begin{array}{l}\text { Setelah mengikuti perkuliahan mahasiswa diharapkan dapat menjelaskan: } \\
\text { 1. Konsep Ekonomi } \\
\text { 2. Konsep Syariah } \\
\text { 3. Konsep Kebuhan ekonomi Syariah }\end{array}$ & $\begin{array}{l}\text { Mengkaji } \\
\text { konsep } \\
\text { Ekonomi } \\
\text { Syariah }\end{array}$ \\
\hline $\begin{array}{l}\text { Memahami } \\
\text { konsep } \\
\text { perbankan } \\
\text { syariah }\end{array}$ & $\begin{array}{l}\text { Setelah mengikuti perkualiahan mahasiswa diharapkan dapat menjelaska: } \\
\text { 1. Prinsip dasar perbankan syariah } \\
\text { 2. Elemen-elemen Perbankan syariah } \\
\text { 3. Ciri-ciri perbankan syariah }\end{array}$ & $\begin{array}{l}\text { Mengkaji } \\
\text { konsep } \\
\text { perbankan } \\
\text { syariah }\end{array}$ \\
\hline $\begin{array}{l}\text { Memahami } \\
\text { Prduk-produk } \\
\text { perbankan } \\
\text { syariah }\end{array}$ & $\begin{array}{l}\text { Setelah mengikuti perkualuahan ini mahasiswa diarapkan dapat } \\
\text { menjelaskan: } \\
\text { 1. Prduk-produk perbankan syariah } \\
\text { 2. Penghimpunan dan penyaluran dana }\end{array}$ & $\begin{array}{l}\text { Mengkaji } \\
\text { Produk- } \\
\text { produk } \\
\text { perbankan } \\
\text { syariah }\end{array}$ \\
\hline $\begin{array}{l}\text { Memahami } \\
\text { konsep } \\
\text { keuangan } \\
\text { syariah }\end{array}$ & $\begin{array}{l}\text { Setelah mengikuti perkuliahan mahasiswa dapat menjelaskan: } \\
\text { 1. Konsep uang dalam Islam } \\
\text { 2. Teori-teori keuangan syariah } \\
\text { 3. Konsep hak kepemilikan }\end{array}$ & $\begin{array}{l}\text { Mengkaji } \\
\text { konsep fiqh } \\
\text { muamalat }\end{array}$ \\
\hline $\begin{array}{l}\text { Memahami } \\
\text { fiqh muamalat }\end{array}$ & $\begin{array}{l}\text { Setelah mengikuti perkuliahan ini mahasiswa dapat menjeaskan: } \\
\text { Memahami fungsi dan persyaratan akad transaksi } \\
\text { Mengelompokan jenis-jenis akad transaksi } \\
\text { Memahami akad transaksi dalam bank syariah }\end{array}$ & $\begin{array}{l}\text { Mngkaji } \\
\text { konsep fiqh } \\
\text { muamalah }\end{array}$ \\
\hline
\end{tabular}

(Hasil Analisis Data)

pembelajaran perbankan syariah. Indikator pembelajaran dirumuskan dengan melihat kompetensi dasar dari pembelajaran. Indikator pembelajaran perbankan syariah FEBI UIN raden fatah Palembang dapat dilihat pada tabel berikut:

(Hasil Analisis Data) 


\section{Jurnal Ilmiah Ekonomi Islam, 6(03), 2020, 626}

c. Penyesuaian kurikulum

Penyesuaian kurikulum perbankan syariah FEBI UIN Raden Fatah ini disesuaikan dengan kebutuhan lapangan dalam rangka menciptakan para lulusan (SDM) yang disesuaikan dengan lembaga keuangan bank syariah. Sehingga perlu ditingkatkan lagi agar terciptanya kesesuaian antara kebutuhan institusi dan lembaga keuangan syariah. Kurikulum yang telah mengalami penyesuaian di Program studi Perbankan Syariah UIN Raden Fatah adalah sebagai berikut:

\begin{tabular}{|c|c|c|c|}
\hline $\mathrm{NO}$ & Kode & Mata Kuliah & SKS \\
\hline 1 & UIN & Kewarganegaraan & 2 \\
\hline 2 & UIN & Bahasa Inggris & 2 \\
\hline 3 & SPS & Kewirausahaan & 2 \\
\hline 4 & UIN & Islam dan Ilmu Pengetahuan & 2 \\
\hline 5 & SPS & Fiqh Muamalah & 2 \\
\hline 6 & SPS & Statistik Dasar & 3 \\
\hline 7 & SPS & $\begin{array}{l}\text { Pengantar Pasar Modal } \\
\text { Konvensional dan Syariah }\end{array}$ & 2 \\
\hline 8 & SPS & $\begin{array}{l}\text { Akuntansi Keuangan } \\
\text { Menengah }\end{array}$ & 3 \\
\hline 9 & SPS & Etika Perbankan Syariah & 2 \\
\hline 10 & SPS & Islam dan Peradaban Melayu & 2 \\
\hline 11 & SPS & Fiqh Muamalah Kontemporer & 3 \\
\hline 12 & SPS & Statistik Lanjutan & 3 \\
\hline 13 & SPS & Analisi Laporan Keuangan & 3 \\
\hline 14 & SPS & Manajemen Keuangan & 3 \\
\hline 15 & SPS & $\begin{array}{l}\text { Tafsir ayat dan Hadits } \\
\text { Ekonomi }\end{array}$ & 3 \\
\hline 16 & SPS & Ekonomi Mikro Islam & 2 \\
\hline 17 & SPS & Manajemen Pemasaran Islam & 2 \\
\hline 18 & SPS & $\begin{array}{l}\text { Bahasa Inggris Bisnis dan } \\
\text { Perbankan }\end{array}$ & 2 \\
\hline 19 & SPS & Ekonomi Makro Islam & 3 \\
\hline 20 & SPS & Studi Kelayakan Bisnis Islam & 3 \\
\hline 22 & SPS & Perpajakan & 3 \\
\hline 23 & SPS & $\begin{array}{l}\text { Manajemen Investasi dan } \\
\text { Fortopolio }\end{array}$ & 3 \\
\hline 24 & SPS & $\begin{array}{l}\text { Manajemen Lembaga } \\
\text { Keuangan }\end{array}$ & 2 \\
\hline 25 & SPS & Hukum Bisnis dan Perbankan & 2 \\
\hline 26 & SPS & Manajemen Ziswaf & 2 \\
\hline 27 & SPS & Ekonometrika & 3 \\
\hline 28 & SPS & Praktikum Akuntansi & 2 \\
\hline 29 & SPS & Akuntansi Biaya & 2 \\
\hline 30 & SPS & Ekonomi Moneter & 2 \\
\hline 31 & SPS & Praktikum Bank Mini & 3 \\
\hline 32 & SPS & Ekonomi Internasional & 2 \\
\hline 33 & SPS & Komunikasi Bisnis & 2 \\
\hline
\end{tabular}

\begin{tabular}{|l|l|l|l|}
\hline 34 & SPS & Perilaku Organisasi & 2 \\
\hline 35 & SPS & Praktikum Statistik & 2 \\
\hline 36 & SPS & Manajemen Resiko & 2 \\
\hline 37 & SPS & Metodologi Penelitian & 2 \\
\hline 38 & SPS & Manajemen Strategis & 3 \\
\hline 39 & SPS & Manajemen SDI & 3 \\
\hline 40 & SPS & Sistem Informasi Manajemen & 2 \\
\hline 41 & SPS & $\begin{array}{l}\text { Manajemen Pembiayaan } \\
\text { Perbankan Syariah }\end{array}$ & 3 \\
\hline 42 & SPS & $\begin{array}{l}\text { Manajemen Perbankan } \\
\text { Syariah }\end{array}$ & 3 \\
\hline 42 & SPS & Manajemen Operasional & 3 \\
\hline 43 & SPS & Sistem Informasi Akuntansi & 3 \\
\hline 44 & SPS & Akuntansi Perbankan Syariah & 3 \\
\hline 45 & SPS & Akuntansi Zizwaf & 3 \\
\hline 46 & SPS & Auditing & 3 \\
\hline
\end{tabular}

Sumber: Buku Pedoman Akademik Prodi S1 Perbankan Syariah

d. Pendekatan/Strategi/Model/Metode Pembelajaran 1) Metode Ceramah

Metode ini biasa digunakan oleh dosen-dosen terkait dengan matakuliah-mata kuliah yang membutuhkan tingkat pemamahan yang lebih mendalam kepada mahasiswa, agar materi tersebut dapat langsung disampaikan oleh dosen dan diterima langsungjuga oleh mahasiswa. Mata kuliah-matakuliah tersebut diantaranya; kewarganegaraan, Islam dan Ilmu Pengetahuan, Fiqh Muamalah, Islam dan peradaban Melayu, ayat dan hadits ekonomi, tafsir ayat dan hadist, Ekonomi mikro Islam, Ekonomi makro Islam, Hukum bisnis dan perbankan.

2) Metode Reteso dan Tugas

Dalam proses pembelajaran metode retisi selalu digunakan oleh dosen Fakultas Ekonomi dan Bisnis Islam. Dari hasil penelitian ditemukan bahwa $90 \%$ dosen menggunakan metode retesi ini untuk mengukur tingkat penguasaan mahasiswa terkait materi yang diberikan dosen. Selain itu dosen memberika tugas juga untuk merangsang peserta didik untuk belajar menanamkan tangung jawab mahasiswa terkait amanah yang berikan dosen kepadanya, karena metode retisi ini diberika diluar kegiatan pembelajaran yang ada di kelas. Metode ini juga digunakan untuk mengasah dan melati daya kritis mahasiswa dan berpikir bebas ilmiah 


\section{Jurnal Ilmiah Ekonomi Islam, 6(03), 2020, 627}

terhadap fenomena-fenoma yang terkait dengan materi kuliah.

3) Metode Diskusi

Metode diskusi digunakan dengan penyajian materi dengan menugaskan pesera didik untuk melakukan dialog ilmiah terkait materi perkuliahan. Pada metode ini ada beberapa dosen menggunakannya, karena tidak semua mata kuliah dapat disajikan dengan metode diskusi. Dari data memperlihatkan mata kuliahmata kuliah yang disajikan dengan metode diskusi diantaranya kewarganegaraan, Islam dan ilmu pengetahuan, Fiqh muamalah, Islam dan Peradaban Melayu, Tafsir ayat dan hadits ekonomi, ekonomi makro dan ekonomi mikro, hukum bsnis dan perbankan, manajemen ziswaf.

4) Metode Kelompok kerja

Metode pemelajaran dengan menggunakan kelompok kerja dilakukan oleh beberapa dosen dengan cara membagi beberapa kelompok, kemudian peserta didik membahas secara bersama menyelesaikan masalah dan menjelaskan tugas tertentu dan berusaha mencapai tujuan pengajaran yang ditentukan oleh peserta didik. Permasalahan yang disajikan bertujuan untuk menumbuhkan sifat kritis dan tingkat analisis dari peserta didik.

5) Metode Pembelajaran Pemecahan Masalah (Problem Solving)

Meode ini juga memiliki kebaikan dalam hal merangsang mahasswa untuk melakukan pengembangan kemampuan berpikir peserta didik secara kreatif dan menyeluruh. Metode ini akan memunculkan mahasiswa menjadi kreatif baik dalam hal pemikiran maupun tindakan. Kita ketahui bahwa seiring perkembangan digital dalam dunia perbankan membutuhkan kreativitas dalam penggunaannya.

\section{e. Media/Alat Bantu/Sumber Pembelajaran}

Salah satu model pembelajran perbankan syariah yang dilakukan oleh program studi perbankan syariah adalah dengan melakukan pembedayaan laboratorium bank mini. Hal ini akan menunjung peningkatan kompetensi peserta didik. Pembelajran Praktikum Laboratorium bank mini dengan variabel kerumitan aplikasi, fasilitas, metode penyampaian bahan ajar memiliki pengaruh terhadap peningkatan skill mahasiswa. Dalam melakukan penguatan sistem laboratorium perbankan maka diperlukan kerjasama dengan pihak lain (Zuhro, 2012). Untuk itu Laboratorium bank Mini Fakultas Ekonomi dan Bisnis Islam UIN Raden Fatah melakukan kerjasama dengan pihak Bank Rakyat Indonesia Syariah (BRIS). Dalam konsepya, Laboratorium memiliki diidsain untuk proses pembelajaran, proses penelitian dan kegiatan yang lain yang mendukung proses peningkatan kualaitas mahasiswa dan dosen. Secara umum fungsi laboratorium sebagai berikut (Hamdani dan Kurniantanti, 2008):

1) Sebagai tempat berlangsungnya kegiatan belajar yang memerlukan peralatan khusus

2) Sebagai tempat yang mendorong semangat mahasiswa untuk memperdalam pengertian suatu fakta yang diselidiki atau diamati

3) Tempat display atau pameran

4) Tempat untuk belajar memahami karakteristik alam dan lingkungan.

5) Sebagai tempat melatih proses pembelajaran

\section{KESIMPULAN}

Berdasarkan hasil penelitian diatas maka dapat disimpulkan bahwa urgensi dari rekonstruksi pembelajaran perbankan syariah adalah karena kurikulum dan model pembelajaran perbankan syariah belum menjawab dari tingkat keilmuan yang dibutuhkan dalam perbankan syariah. Sementara untuk mewujudkan rekonstruksi pembejaran perbankan syariah yang lebih baik maka dilakukan beberapa langkah diantaranga menentuan capaian pembelajaran, menentukan indikator pencapaian pembejaran, menentukan kurikulum, dan penentuan metode pembejaran. Dalam penelitian ini memiliki keterbatasan yaitu penelitian ini belum mencakup langkah yang lebih strategis ketika langkah-langkah rekonstruksi pembelajaran diungkap. Maka dibutuhkan penelitian lebih lanjut dalam merumuskan kurikulum perbankan syariah yang lebih komprehensif.

\section{UCAPAN TERIMA KASIH}

Terimakasih penulis ucapkan untuk seluruh pihak yang terkait dalam pengumpulan data penelitian ini diantaranya Civitas akademika Fakultas Ekonomi dan Bisnis Islam UIN Raden fatah Palembang, Praktisi Perbankan Syariah, Mahasiswa Program Studi Perbankan Syariah. 
Jurnal Ilmiah Ekonomi Islam, 6(03), 2020, 628

\section{REFERENSI}

Aisyah, Esy Nur, Siswanto Siswanto Siswanto, and Yayuk Sri Rahayu, (2018) 'Mewujudkan Lembaga Keuangan Mikro Syariah Berbasis Laboratorium', El Dinar, 6.1, 29 <https://doi.org/10.18860/ed.v6i1.5452>

Jasman Ginting Muthe (2012), 'UNIVERSITAS INDONESIA PROYEKSI KEBUTUHAN SUMBER DAYA MANUSIA ( SDM ) PERBANKAN SYARIAH DAN SKENARIO PEMENUHANNYA UNIVERSITAS INDONESIA PROYEKSI KEBUTUHAN SUMBER DAYA MANUSIA ( SDM ) TESIS
Diajukan Sebagai Salah Satu Syarat Untuk Memperoleh Gelar',

Nur, Mohammad, Rianto Al, and Euis Amalia (2016), 'Kesesuaian Pembelajaran Ekonomi Islam Di Perguruan Tinggi Dengan', August, 2016 <https://doi.org/10.13140/RG.2.1.2229.5764>

Wahab, Abdul, Urgensi Kurikulum, Perbankan Syariah, and Perguruan Tinggi, 'URGENSI KURIKULUM PERBANKAN SYARIAH PERGURUAN TINGGI TERHADAP SUMBER DAYA MANUSIA INDUSTRI PERBANKAN SYARIAH Abdul Wahab', 93-104 